\title{
AN ELISA METHOD USING SERUM DERIVED HDAg FOR THE SOROLOGICAL DETECTION OF HDV ANTIGENS AND ANTIBODIES
}

Celso GRanato (1), Edna STRaUSS (2), Ludmila VTTVITSKX (3), Luiz Carlos da Costa GaYoTto (2)

\& Christian TREPO (3)

\section{S U M M A $\mathbf{Y}$}

One of the main difficulties related to the detection of the Hepatitis Delta Virus (HDV) antigen and antibody has been the source of the needed HD an. tigen since HDV containing human and animal livers are very difficult to obtain and since yield is low. This fact prompted us to try to use the serum of patients in the acute phase of HDV infection as a source of HDAg and turn to erizyme immunoassays (EIA) instead of RIA for the sake of easiness and economy in the amount of HDAg needed.

The antigen for EIA was obtained from patients during the acute phase of HDV infection and the antibody from patients who have been carriers for many years.

For the detection of the antigen, a sandwich type method was employed, whereas for the antibody a competition assay was developed.

In order to assess the relative specificity and sensibility of the test, the antibody assay was compared to a commercial RIA (C. RIA, Abbott) and to a non-commercial RIA (NC RIA).

Forty-two sera were tested by the two methods and only in two cases discrepant results were obtained.

Its is concluded that: 1) sera from patients in the acute and chronic phases of $\mathrm{HDV}$ infection can be used as source of both antigen and antibody, for im. munoassays; 2) EIA and RIA have comparable relative specificity and sensibility and 3) EIA is easier to perform, cheaper, non-hazardous, has a longer shelf-life and saves scarce HDAg.

KEY WORDS: Hepatitis; Hepatitis delta virus; Enzyme immuno assay.

\section{N T R O D U C T I O N}

The identification of the Hepatitis Delta Virus (HDV) has provided additional insight into the heterogeneity of Hepatitis ${ }^{5}$. In certain areas of the world and in some high risk groups, HDV associated Hepatitis may exhibit some especific features. The course of the hepatitis $B$ virus (HBV) infection can be abruptly altered by superinfection with HDV and a prior assimptomatic HBV carrier state is turned into a rapidly progressive disease leading to cirrhosis and liver failure.

In this context, for both diagnostic purposes and epidemiological studies the detection of HDV associated antigen and antibody represents a crucial tool for the study of liver

(1) Hepatitis Laboratory - Instituto Adolfo Lutz. Av. Dr. Arnaldo, 355. CEP 01246 São Paulo, SP., Brasil.

(2) Liiver Unit - Faculdade de Medicina da Universidade de São Paulo.

(3) Unite 271 - INSERM - Lyon, France.

Supported by grants from International Cooperation Program. CNPq/INSERM/FINEP n.० 0190.200.259/84. 
GRANATO, C.; STRAUSS, F.; VITVITSKY, L.; GAYOTTO, L. C. da C. \& TREPO, C. - An ELISA method using serum derived HDAg for the sorological detection of HDV antigens and antibodies. Rev. Inst. Med. trop. São Paulo, 29: $388-391,1987$.

disorders. One of the key problems concerning HDV detection is linked to the source of HDV antigen. While most HDV infected patient serum are positive for anti-HDV at high titers, the antigen on the contrary is rarely detected, only in small amounts and for a limited period of time at the onset of the disease. For this reason, the source of $\mathrm{HDAg}$ used to be the liver of patients who died of HDV hepatitis or cirrhosis since this organ showed a reasunable quantity of the antigen ?,6. Some laboratories have also utilized livers of woodchucks experimentally superinfected with HDV (C. TREPO, pers. communic.). However such procedures have highly limiting factors, not only because of limited number of livers, but also because of the difficulties linked to the obtention of HDAg, since it is complexed with anti-HD within liver cells.

This drawback has prompted us to try another source of antigen. For this purpose we utilized sera of patients in the acute phase of $\mathrm{HDV}$ infection, as previously reported for the detection of $\mathrm{HDV}$ and $\mathrm{HBV}$ using radioimmunoassays (RIA). Instead of RIA we developed an enzyme-linked assay (EIA) for the detection of HDV antigen and antibody. In a second step, we compared this new assay with a commercial RIA that uses woodchuck liver derived antigen and a non-commercial RIA test that uses human serum as antigen source.

\section{MATERIAL AND METHODS}

Source of reagents - For the development of this EIA, the source of anti-HD was the serum of a patient which reached anti-HD titers of $10^{-5}$.

IgG was fractioned by salt precipitation and ionexchange chromatography (DEAE-Sephadex). The purified IgG fraction was used to coat the wells of polyvinylchloride microdilution plates and was coupled to horse-radish peroxidase (HRPO), according to NAKANE et al 4. The source of HDAg was the serum of a patient with acute fulminant HDV infection whose serum was obtained in large amounts through plasma exchange used as a life-sup. porting measure.
Detection of HDAg - For the detection of HDAg a sandwich assay proved to be the best approach. Sera were tested undiluted but a solution of non-ionic detergent NP-40 (final dilution $0,5 \%$ ) 'was used to realease delta antigen from the lipoprotein coat of HBsAg. Seventy microliters of serum were added to 30 microlitres of NP-40 and the mixture was first incubated with the anti-HD coated solid-phase for 2 hours at room temperature and then overnight at $4^{\circ} \mathrm{C}$. After washing, the anti-HD peroxidase complex was added at a suitable dilution and incubated for 3 hours at room temperature. The reaction was revealed by color development after addition of ortho-phenile-diamine and read in a spectrophotometer.

Detection of anti-HD - For the detection of anti-HD the serum positive for HDAg was used initially to react with the antibody coated solid-phase. For this particular serum, a dilution of $10^{-2}$ has shown to be adequate for the following steps. The detergent solution and the incubation time were the same as those described for antigen detection. After washing. the sera to be tested were added at a dilution of $10^{-1}$ in PBS together with the diluted conjugate (anti-HD-HRPO); the mixture was left to react for three hours. The color development was obtained in the same way as that used for antigen detection. In this case, however, color development occured in negative sera and a certain decrease in the optical density was observed in the positive sera, when compared with the negative control. A serum was considered positive when a reduction of $\mathbf{5 0 \%}$ in the absorbance of the negative control was determined. Whenever the result (CPM or O.D.) remained 'within $10 \%$ of the cut off value, despite retesting, the result was con. sidered as inconclusive.

Comparison of methods - For the com. parative assays, a RIA developed in the Unité 271 INSERM and a Commercial RIA (Abbott Laboratories, North Chicago, III) were used. Sera from 42 patients suspected on clinical and epidemiological grounds of HDV infection were tested for the three methods.

\section{RESULTS}

As shown in table 1 the results obtained after testing 42 sera by Commercial RIA (C. 
GRANATO; C.: STRAUSS, E:; VITVITSKY, L.; GAYOTTO, L. C. da C. \& TREPO, C. - An ELISA method using serum derived HDAg for the sorological detection of HDV antigens and antibodies. Rev. Inst. Med. trop. São Paulo, 29: 388-391, 1987.

RIA), non-commercial RIA (NC-RIA) and EIA are very similar indeed. Only weakly positive sample by RIA scored inconclusive by EIA.

T A B L E I

Comparative results of Commercial RIA (C-RIA), Non-commercial RIA (NC-RIA) and Enzyme immune assay (EIA)

\begin{tabular}{lccc}
\hline Results & C-RIA & NC-RIA & EIA \\
\hline Positive & 22 & 22 & 21 \\
Negative & 19 & 19 & 19 \\
Inconclusive & 01 & 01 & 02 \\
Total & 42 & 42 & 42 \\
\hline
\end{tabular}

The discrepant results in two cases are shown in table 2.

T A B L E II

Discrepant results in the comparison of the three methods

\begin{tabular}{clll}
\hline N.o Serum & C-RIA & NC-RIA & EIA \\
\hline 21 & positive & negative & inconclusive \\
34 & negative & positive & negative \\
\hline
\end{tabular}

No serum was positive for HDAg by EIA, although the antigen positive reference serum was always positive by EIA.

\section{COMMENTS}

The serological diagnosis of HDV associated infection relies on the detection of antibodies directed to the HDAg. This method detects mainly IgG antibodies' and for this reason can not precisely differenciate acute from chronic infection.

It has been reported that persisting detection of IgM anti-HD correlates well with the detection of HDAg in liver ${ }^{3}$, in either acute HDV infection or ongoing viral replication. The detection of anti-HD IgG would than ve used to identify the etiology of chronic infection or at least to detect previous contact with HDV, especially in epidemiological surveys.

The methodology employing serum derived antigen has already been used by one of us 1 for the detection of anti-HBc with good results, and for the HDAg 7,8 .

In this study, comparison was made between liver and serum derived antigens using RIA, and at the same time RIA and EIA were compared using the same serum derived anti- gen. In all instances the results were remarkably similar and only in two out of 42 samples they were considered inconclusive.

This method has been in routine use in our laboratory for the last two years without reduction of the activity of both the antigen and the conjugate, which is a problem when RIA is used. Moreover, the possibility of using sera at a relatively higher dilution, than that used for RIA, overcomes the problem of antigen supply. With $10 \mathrm{ml}$ of HDAg containing serum it is possible to test more than 14,000 samples for anti-HD. Furthermore, the feaseability of a EIA for the detection of HDV markers brings itself the various advantages of an accessible, simple, inexpensive and nonhazardous technique.

\section{RESUMO}

Método imunoenzimático usando antigeno delta derivado do soro para detecção sérica de antigeno e anticorpo do vírus da hepatite delta.

Um dos maiores problemas no desenvolvimento de metodologia para detecção de antígenos e anticorpos do vírus da hepatite delta (VHD) tem sido a fonte de antígenos, uma vez que fígados humàos e de animais infectados pelo VHD são de difícil obtenção e baixo. rendimento

Ao uso de soro de pacientes na fase aguda da infecção pelo VHD, como fonte de antígenos, associamos a técnica imunoenzimática, com finalidade de facilitar o manuseio e economizar antígeno.

$O$ antígeno delta foi obtido a partir do soro de indivíduo na fase aguda de infecção por VHD e o anticorpo a partir de soro de portadores crônicos de VHD.

Parż a detecção do antígeno foi empregado o método "sanduiche" e para a detecção do anticorpo um ensaio tipo competição.

Visando testar a especificidade e a sensibilidade relativas do novo método de detecção de anticorpo, foram feitas comparaçōes do mesmo com radio-imunoensaio comercial (CRIE, Lab. Abbott) e um radio-imunoensaio desenvolvido na Unité 271-INSERM de Lyon, França (NC-RIA). 
GRANATO, C.; STRAUSS, E.; VITVITSKY, L.; GAYOTTO, L. C. da C. \& TREPO, C. - Ani ELISA method using serum
derived HDAg for the sorological detection derived HDAg for the sorological detection of HDV antigens and antibodies. Rev. Inst. Med. trop. São Paulo, 29:
388-391, 1987.

Soros de 42 pacientes foram testados pelos três métodos, sendo observados resultados discrepantes em apenas 2 casos. Os autores concluem que: 1) soros de pacientes na fase aguda e crônica da infecção pelo VHD podem ser usados como fonte de antígeno $e$ anticorpos em ensaios imunológicos 2) o EIE e o RIE tem especificidade e sensibilidade relativas comparáveis 3) o EIE é de fácil execução, mais barato, não poluente, tem vida útil maior, além de proporcionar economia de antígeno.

\section{REFERENCES}

1. BREDEHORST, R.; von WULFFEN, H. \& GRANATO, C. - Quantitation of hepatitis B virus core antigen in serum in the presence of antibody to $\mathrm{HBV}$ core antigen: comparison with assays of serum HEV, DNA polymerase and HBV e antigen. J. clin. Microbiol., 21: 593-598, 1985.

2. CRIVELLI, O.; RIZZETTO, M.; LAVARINI, C.; SMEDILE, A. \& GERIN, J-L. - Enzyme-linked immunosorbent assay for detection of antibody to the hepatitis B surface antigen associated delta antigen. $J$. clin. Microbiol., 14: 173-177, 1981.

3. FARCI, P.; GERIN, J. L.; ARAGONA, M.; IIINDSAY, I.; CRIVELLI, O.; BALESTRIERI, A.; SMEDILE, A.; THOMAS, H. C. \& RIZZETTO, M. - Diagnostic and prognostic significance of IgM antibody to the hepa titis delta virus. J. Amer. med. Ass., 255: 1443-1446, 1986.

4. NAKANE, P. K. \& KAWAOI, A. - Peroxidase-labeled antibody: a new method of conjugation. J. Histochem. Cytochem., 22: 1084-1091, 1974.

5. RIZZETTO, M.; CANESE, M. G.; ARICO, S.; CRIVELII, O;; TREPO, C.; BONINO, F. \& VERME, G. - Immunofluorescence of a new antigen antibody system (delta/anti-delta) associated to hepatitis $B$ virus in liver and in serum, of HBsAg carriers. Gut, 18: $997-1003,1977$.

6. RIZZETTO, M.; SHIF, J. W. K. \& GERIN, J. L. -The hepatitis B virus-associated delta antigen: isolation from liver, development of solid-phase raioimmunoassay for delta and anti-delta and parcial characterization of delta. J. Immunol., 125: 318-324, 1980.

7. RIZZETTO, M.; PURCELL, R. H. \& GERIN, J. L. - Epidemiology of HBV associated delta agent: geographical distribution of anti-delta and prevalence in polytransfused HE's Ag carriers. Lancet, 1: 1215-1218, 1980.

8. SHATTOCK, A. G. \& MORGAN, B. M. - Sensitive enzyme immunoassay for the detection of delta antigen and delta antibody, using serum as the delta antigen source. J. med. Virol., 13: 78-82, 1984.

Recebido para publicação em $3 / 7 / 87$. 